\title{
Role of Antibiotic Production in Suppression of Radish Damping-off by Seed Bacterization with Pseudomonas cepacia*
}

\author{
Yoshihisa HommA** and Takahito Suzui**
}

\begin{abstract}
Strains RB425 and RB3292 of Pseudomonas cepacia, isolated originally from roots of lettuce and Campanula sp. and known producers of the antibiotics pyrrolnitrin and two pseudane compounds, both were suppressive to damping-off of radish caused by Rhizoctonia solani AG4 when applied on radish seeds. Two other naturally occurring strains A2 and A4 of $P$. cepacia, causal agents of bacterial brown spot of Cymbidium spp., and known producers of pyrrolnitrin (but not the two pseudanes), also were suppressive to damping-off of radish. A fifth strain, P. cepacia ATCC No. 25416, produced no detectable quantity of any of the three antibiotics and was not suppressive to damping-off of radish. Eight mutants of strain RB425, induced by nitrosoguanidine (NTG), were distinguished from the wild-type parent by colony morphology. Three of these mutants produced no detectable quantities of either pyrrolnitrin or the two pseudanes in liquid culture and provided no suppression of damping-off. The other five mutants produced the three antibiotics in amounts similar to the parent and were suppressive to damping-off. Tests with derivative strains resistant to rifampicin and nalidixic acid showed that the mutants were not significantly different from the parent in the ability to colonize the roots of radish seedlings. Both colonization of radish seedlings by $R$. solani and severity of damping-off of radish caused by this fungus were suppressed by about $50 \%$ when the radish seeds were coated with either living cells of RB425 $\left(10^{7} \mathrm{cfu} / \mathrm{seed}\right)$ or purified pyrrolnitrin $(1.0 \mu \mathrm{g} / \mathrm{seed})$. Damping-off was suppressed only slightly or not at all following seed treatment with either of the two pseudane compounds, even at $40 \mu \mathrm{g} / \mathrm{seed}$. Observations by SEM confirmed that the effective strains multiplied in the spermosphere and the rhizosphere of radish seedlings. These results indicate that pyrrolnitrin plays an important role in suppression of radish damping-off by seed bacterization with $P$. cepacia.
\end{abstract}

(Received July 26, 1989)

Key words: antagonist, Pseudomonas cepacia, antibiotics, bacterization, biological control, soilborne pathogen.

\section{INTRODUCTION}

Some soilborne pathogens have been successfully restricted in their disease-producing activity by bacterization of the planting materials (seeds, tubers, cuttings or roots) of the host plants with root-colonizing bacteria ${ }^{1,4)}$. Successful control of root diseases by bacterization has been attributed to the ability of the bacteria to rapidly colonize the rhizosphere, effect quantitative and qualitative changes in the rhizosphere microflora, and suppress the activity of pathogens

* The research was supported in part by a research grant from the Ministry of Agriculture, Forestry and Fisheries of Japan.

** Department of Microbiology, National Institute of Agro-Environmental Sciences, Kannondai 3-1-1, Tsukuba, Ibaraki 305, Japan

農業環境技術研究所 
in the infection court ${ }^{4}$. Disease suppression has been attributed to the ability of the bacteria to produce either antibiotics, such as pyrrolnitrin ${ }^{10)}$, pyoluteorin ${ }^{11)}$ or phenazine ${ }^{6)}$, or siderophores, e.g. pseudobactin, inhibitory to major or minor pathogens in the rhizosphere ${ }^{6,10,11)}$. Analytical techniques for detection of antibiotics have been improved greatly during recent years, but direct demonstration of the production of antibiotics by microorganisms in rhizosphere is still difficult. Evidence for a role of antibiotic production by introduced microorganisms in biological control of soilborne pathogens has been obtained by using isogenic mutants that produce less or no antibiotic ${ }^{12,21}$, or by applying purified antibiotics isolated from the antagonists to seeds and demonstrating a suppressive effect on disease ${ }^{10,11)}$, and now also by direct isolation of the antibiotic from rhizosphere soil ${ }^{21)}$.

Pseudomonas cepacia (Burkholder) Palleroni et Holmes was initially described as a cause of sour skin of onion bulbs ${ }^{2}$ but was subsequently reported to provide biological control of certain soilborne pathogens ${ }^{8,14)}$ and to produce several antibiotics ${ }^{9,15,18)}$. Strains of $P$. cepacia exhibited strong antibiosis to Fusarium oxysporum Schl. f. sp. cepae (Hanz.) Snyd. et Hans. in vitro and suppressed the incidence of Fusarium-wilt of onion when introduced on the seed ${ }^{14)}$. We previously reported $^{8}$ ) that a strain of $P$. cepacia, obtained from lettuce roots and tested in pots, controlled damping-off of radish caused by Rhizoctonia solani Kühn, Verticillium-wilt of eggplant caused by Verticillium dahliae Klebahn, and Fusarium-wilt of tomato caused by $F$. oxysporum f. sp. lycopersici. This same strain also produced antibiotics in culture, namely pyrrolnitrin and two pseudane compounds ${ }^{9}$.

This paper deals with the relation between production of the antibiotics in vitro and suppression of disease in vivo among several naturally occurring strains and nitrosoguanidine (NTG)-induced mutants of $P$. cepacia, and the relative efficacy of seed treatment with live bacteria versus purified antibiotics on colonization of $R$. solani in the rhizosphere of radish seedlings and on suppression of damping-off caused by $R$. solani.

\section{MATERIALS AND METHODS}

Naturally occurring strains and mutants of P. cepacia. Five naturally occurring strains of $P$. cepacia were used in this study. Strains RB425 and RB3292 were obtained, respectively, by dilution plating of macerates of washed roots of lettuce grown in Ibaraki Prefecture $^{8)}$ and Campanula sp. grown in Saitama Prefecture. Strains A2 and A4 were reported to cause a bacterial brown spot of Cymbidium spp. ${ }^{22}$ The fifth was ATCC No. 25416 of $P$. cepacia.

Bacterial cells of $P$. cepacia RB425 were suspended at $1.5 \times 10^{7} \mathrm{cfu} / \mathrm{ml}$ in $10,40,100,200$ and $400 \mathrm{ppm}$ of 1-methyl-3-nitro-1-nitrosoguanidine (NTG, Sigma Chem. Co., St. Louis, MO 63178, USA) and incubated for 10, 20,30, 40 and 60 min at $30 \mathrm{C}$. Mutants were obtained from single colonies grown on the plate of PPGSA ${ }^{9)}$ in which about $1 \%$ of bacteria survived after spread-plating the treated suspension and incubating at $28 \mathrm{C}$ for 5 days. Eight mutants were selected for further experiments from among 443 isolates obtained after mutagenesis; five were still inhibitory to $R$. solani on Czapek-Dox agar but three were no longer inhibitory in these test. These eight mutants were then used i) to estimate production of the pyrrolnitrin and the two pseudane derivatives [2-(2-heptenyl)-3-methyl-4-quinolinol, HMQ, and 2-(2-nonenyl)-3methyl-4-quinolinol, NMQ], in culture solution and ii) evaluate the role of these antibiotics in suppression of radish damping-off caused by $R$. solani. Growth of these strains in PPGS solution was verified by optical density (UV $254 \mathrm{~nm}$ ) after 3 days at $28 \mathrm{C}$. These mutants were also tested for ability to cause lesions on onion; an onion scale was peeled from a fresh onion bulb and cut into four pieces, and each piece was inoculated by a toothpick with bacterial cells of each of the four strains and incubated in a moist chamber in darkness at $25 \mathrm{C}$ for 3 days.

Four of the original eight NTG-mutants together with the parent were selected for studies of root-colonizing ability. Each antibiotic-resistant strain of RB425 and its NTG-induced mutants, designated as RB425 $\mathrm{R}^{\mathrm{R}} \mathrm{NA}^{\mathrm{R}}$, NTG-102 $\mathrm{R}^{\mathrm{R}} \mathrm{NA}^{\mathrm{R}}$, NTG-218 $\mathrm{R}^{\mathrm{R}} \mathrm{NA}^{\mathrm{R}}$, NTG-348 $\mathrm{R}^{\mathrm{R}_{-}}$ 
NA ${ }^{R}$ and NTG-403 $R^{R} N^{R}$, was obtained by successively culturing strain RB425 and the mutants on PPGSA medium containing a ranged concentrations $(10,20,50,100 \mathrm{ppm})$ of rifampicin and nalidixic acid, respectively. Antibiotic-resistant derivative strains were subcultured at $28 \mathrm{C}$ for 2 days on PPGSA medium containing $100 \mathrm{ppm}$ of both antibiotics before use. These strains were used for monitoring the population on radish seeds and roots after sowing in soil.

Determination of pyrrolnitrin and pseudane derivatives. To measure production of pyrrolnitrin and pseudane derivatives by the strains, each naturally occurring and mutant strain of $P$. cepacia was cultured in flasks $(100 \mathrm{ml})$ of PPGS or $\left.\mathrm{m} 523^{13}\right)$ solution on a reciprocal shaker at $28 \mathrm{C}$ for 3 days. These culture solutions were then extracted with ethyl acetate, fractionated, and purified by silica-gel-column chromatography, gel filtration, and high performance liquid chromatography (HPLC, JASCO TRIROTAR-III, Japan Spectroscopic Co. Ltd., Tokyo, Japan). The biological activity of the various fractions was detected following each fractionation by use of $V$. dahliae grown as an indicator fungus cultured directly on the thin-layer chromatographs (TLC, bioautography). Purified materials were identified to pyrrolnitrin and pseudane derivatives based on i) activity against $V$. dahliae, ii) $R f$-values on TLC, iii) coloration on TLC when sprayed with a $1 \%$ methanol solution of $p$-dimethyl-amino-benzaldehyde, and iv) various spectra such as infrared (IR), nuclear magnetic resonance (NMR) and mass ${ }^{9}$.

Extracts for determination of the amounts of the respective antibiotics produced were obtained from $100 \mathrm{ml}$ of $\mathrm{m} 523$ culture solution by shaking the culture solution twice with an equal volume of ethyl acetate. The extracts were dehydrated with anhydrous sodium sulfate, filtered, and taken to dryness in vacuo. For determination of pyrrolnitrin and pseudane derivatives, the residue was dissolved in $1 \mathrm{ml}$ of $50 \%$ benzene in ethyl acetate and then $1 \mu \mathrm{l}$ of the solution was injected into a gas-liquid chromatograph (GLC, Shimadzu Gas Chromatograph GC-9AM, Shimadzu Seisakusho Ltd., Kyoto, Japan) equipped with a $2.1 \mathrm{~m} \times 0.6 \mathrm{~cm}$ glass column of $1.5 \%$ Silicone OV-17 on chromosorb w. Column temperature was graduated at $5 \mathrm{C} / \mathrm{min}$ from 230 $\mathrm{C}$ to $300 \mathrm{C}$ with $1 \mathrm{~min}$ of initial time; inlet temperature was $340 \mathrm{C}$. The retention times under this condition were 7.2, 10.8 and $13.4 \mathrm{~min}$ for pyrrolnitrin and the two pseudanes (HMQ and NMQ), respectively. When a known amount of the purified antibiotics was added as a mixture to $100 \mathrm{ml}$ of $\mathrm{m} 523$ solution, 85,71 and $74 \%$ of pyrrolnitrin, pseudane (HMQ) and pseudane (NMQ) was recovered, respectively, from the solution using this same method of extraction and quantification.

Seed coating with bacterial cells and antibiotics. Radish seeds were coated with either i) bacterial suspensions, ranging from $10^{5}$ to $10^{8} \mathrm{cfu} / \mathrm{ml}$, ii) pyrrolnitrin solutions at $0.2-10 \mu \mathrm{g} / \mathrm{ml}$, or iii) each the two pseudane derivative in solutions at $2-40 \mu \mathrm{g} / \mathrm{ml}$, separately mixed either with diatomaceous soil or powder of glass beads (100 $\mu \mathrm{m}$ in diam.). The coated seeds were then sown in soil artificially infested with $R$. solani (AG-4). The soil was infested with $2 \%$ (by volume) of the culture in which the pathogen was grown in vermiculite-bran medium at $25 \mathrm{C}$ for 2 days. The isolate of $R$. solani was obtained from a root lesion on Japanese radish obtained in Kagawa Prefecture, Japan. The extent of colonization of the seeds and radicals of seedling by $R$. solani was estimated by the frequency of hyphal growth of $R$. solani from either 25 seeds or 25 radicals from each of three replicates on water agar. The seed coats or radicals were recovered from the soil, washed in distilled water, blotted free of excess water with filter paper, and then plated on the water agar.

Estimation of bacterial population and SEM observation of $P$. cepacia on radish. Radish seeds were soaked in a suspension of cells of $P$. cepacia in $1 \%$ methylcellulose, dried overnight on a clean-air flow bench, and then planted in garden soil (Kureha Engei Bai-Do, Kureha Co. Ltd., Tokyo, Japan) contained in a plastic pot $(8 \times 8 \mathrm{~cm})$. These plants were recovered from the soil at 12, 24 and $48 \mathrm{hr}$ after sowing, gently washed to remove soil particles, and then used for SEM observation of $P$. cepacia on the seeds and radicals of radish. The plants were recovered from the soil at 1,2,3 and 7 days after sowing the seeds coated with strain RB425 $\mathrm{R}^{\mathrm{R}} \mathrm{NA}^{\mathrm{R}}$ or mutant strain $\mathrm{R}^{\mathrm{R}} \mathrm{NA}^{\mathrm{R}}$, and then used for estimation of the bacterial population. 
Bacterial populations on seed surfaces and radicals of radish were estimated by dilution plate counting using a spiral plater (Spiral System Inc., Cincinnati, OH 45244, USA) on PPGSA medium containing $100 \mathrm{ppm}$ each of rifampicin and nalidixic acid. The medium also contained $50 \mathrm{ppm}$ cycloheximide to inhibit fungal growth.

For SEM observation, the radish seedlings were recovered from soil and immediately fixed by immersion for more than $2 \mathrm{hr}$ in $2.5 \%$ glutaraldehyde in $0.1 \mathrm{M}$ phosphate buffer ( $\mathrm{pH} 7.0$ ). The materials were dehydrated in a graded ethanol and isoamyl acetate series, dried by a critical point dryer (Hitachi HCP-2, Hitcahi Koki Co. Ltd., Tokyo, Japan), coated with a platinum paradium layer by an ion spatter-coating apparatus (Eiko "Ion Coater IB-5, Eiko Engineering Co. Ltd., Tokyo, Japan), and then observed under SEM (Hitachi S-450, Hitachi Ltd., Tokyo, Japan).

\section{RESULTS}

\section{Relation between antibiotic production and disease suppression}

Strains RB425 and RB3292 each produced abundant pyrrolnitrin and the two pseudane compounds (HMQ and NMQ) in both of PPGS and m523 solution (Table 1). Strains A2 and A4 produced similar amounts of pyrrolnitrin, compared with RB425 and RB3292, but production of pseudane derivatives was not detected in any of several trials with either of these strains using both PPGS and m523 solution. Neither pyrrolnitrin nor the two pseudanes were detected in culture solutions of strain ATCC No. 25416. The incidence of damping-off in response to seed coating was 73.7 and $71.2 \%$ lower than the check for strains RB425 and RB3292, respectively, 45 and $53.3 \%$ lower than the check for strains A2 and A4, respectively, and only $13.7 \%$

Table 1. Antibiotic production by naturally occurring strains and NTG-induced mutants of Pseudomonas cepacia and the effect of seed-coating with these isolates on severity of radish damping-off caused by Rhizoctonia solani

\begin{tabular}{|c|c|c|c|c|}
\hline \multirow{2}{*}{$\begin{array}{l}\text { Strain of } \\
P . \text { cepacia }\end{array}$} & \multicolumn{3}{|c|}{ Antibiotic production a) } & \multirow{2}{*}{$\begin{array}{l}\% \text { Disease } b \text { ) } \\
\text { suppression }\end{array}$} \\
\hline & Pyrrolnitrin & Pseudane (HMQ) & Pseudane (NMQ) & \\
\hline \multicolumn{5}{|c|}{ Naturally occurring strains } \\
\hline RB425 & 1.47 & 6.88 & 4.29 & $73.7 \mathrm{ab}$ \\
\hline RB3292 & 1.65 & 11.98 & 7.94 & $71.2 \mathrm{abc}$ \\
\hline $\mathrm{A} 2$ & 1.94 & ND & ND & $45.0 \mathrm{e}$ \\
\hline A4 & 1.82 & ND & ND & $53.3 \mathrm{de}$ \\
\hline ATCC No. 25416 & ND & ND & ND & $13.7 \mathrm{f}$ \\
\hline \multicolumn{5}{|c|}{ NTG-induced mutants of RB425 } \\
\hline NTG-34 & ND & ND & ND & g \\
\hline NTG-70 & 3.32 & 14.47 & 11.08 & $76.2 \mathrm{a}$ \\
\hline NTG-102 & 2.02 & 6.64 & 4.58 & $61.2 \mathrm{~cd}$ \\
\hline NTG-218 & 1.84 & 3.80 & 2.46 & $63.7 \mathrm{bcd}$ \\
\hline NTG-233 & 2.15 & 6.94 & 5.31 & $60.0 \mathrm{~cd}$ \\
\hline NTG-348 & ND & ND & ND & $6.2 \mathrm{fg}$ \\
\hline NTG-369 & 2.22 & 7.78 & 6.60 & $58.7 \mathrm{~cd}$ \\
\hline NTG-403 & ND & ND & ND & $0 \mathrm{~g}$ \\
\hline Control inoculation & - & - & - & $0 \mathrm{~g}$ \\
\hline Control non & - & - & - & $100 \mathrm{~h}$ \\
\hline
\end{tabular}

a) $\mu \mathrm{g} / \mathrm{ml}$ of culture solution of $\mathrm{m} 523$ after shaking at $28 \mathrm{C}$ for 5 days. The production of antibiotics as estimated in ethylacetate extracts from the culture solution by gas liquid chromatography. ND: not detected.

b) Decrease $(\%)$ of damping-off of radish comparing with the unprotected check. Values followed by the same letter are not significantly different at $P=0.05$ according to Duncan's multiple range test. 
lower (not significant at $P=0.05$ ) than the check for isolate ATCC No. 25416.

Of the eight mutants selected from among 443 isolates obtained from strain RB425 after NTG mutagenesis, five were inhibitory against $R$. solani on Czapek-Dox agar medium and three were less inhibitory than the parent strain. In addition, colonies of the parent strain RB425 exhibited a dull surface and was yellow green in color, whereas colonies of the eight mutants exhibited a dull to glistening surface and were cream white to yellow-green in color. All mutant strains showed a growth pattern in PPGS solution similar to strain RB425 and all eight, like the parent strain, produced water-soaked lesions on an onion scale in response to toothpickinoculation with bacterial cells. The range of variation in antibiotic production among the eight mutants in culture solution was 0 (ND) $-3.32 \mu \mathrm{g} / \mathrm{ml}$ for pyrrolnitrin, 0 (ND) $-14.47 \mu \mathrm{g} / \mathrm{ml}$ for pseudane HMQ, and $0(\mathrm{ND})-11.08 \mu \mathrm{g} / \mathrm{ml}$ for pseudane NMQ (Table 1). The incidence of radish damping-off caused by $R$. solani, when seeds were coated with these respective mutants, ranged from as much as $76.2 \%$ lower than the check (no bacterization) to no different than the check (Table 1). The correlation coefficients were $r=0.898,0.776$ and $0.752(P<0.01)$ between the disease suppression and the production of pyrrolnitrin, pseudane (HMQ) and pseudane (NMQ), respectively.

\section{Effect of purified antibiotics on seed and root colonization by and on pathogenicity of R. solani}

When radish seeds coated with either increasing concentrations of live cells $\left(10^{5}-10^{8} \mathrm{cfu} /\right.$ seed) of strain RB425 or purified pyrrolnitrin $(0.2-10.0 \mu \mathrm{g} / \mathrm{seed})$ were sown in soil artificially infested with $R$. solani, colonization of the seeds and roots by $R$. solani and the incidence of damping-off caused by $R$. solani all were suppressed in accordance with the concentration of bacterial cells or pyrrolnitrin $(0.2-10.0 \mu \mathrm{g} / \mathrm{seed})$ tested (Table 2). On the other hand, coating the seed with either of the two pseudane derivatives (HMQ and NMQ) at 2.0-40.0 $\mu \mathrm{g} / \mathrm{seed}$ gave no suppression of either colonization of seeds and roots by $R$. solani or incidence of dampingoff (Table 2).

\section{Colonization of radish seeds and roots by $P$. cepacia}

Radish seeds were coated with three different concentrations of parent of strain RB425 $\mathrm{R}^{\mathrm{R}} \mathrm{NA}^{\mathrm{R}}$; the resultant populations on the seed before sowing, counted on the PPGSA containing $100 \mathrm{ppm}$ of each rifampicin and nalidixic acid, was $9.4 \times 10^{6}, 4.7 \times 10^{5}$ and $9.4 \times 10^{4} \mathrm{cfu} / \mathrm{seed}$, respectively. By 2 days after sowing, these populations increased by 1.2-, 1.7- and 6.9-fold, respectively, on the seed (Table 3 ), and were estimated at $4.6 \times 10^{5}, 1.8 \times 10^{4}$ and $5.3 \times 10^{3} \mathrm{cfu} /$ radical, respectively. At 7 days after sowing, the populations were estimated at $10.2 \times 10^{6}$, $1.2 \times 10^{5}$ and $3.5 \times 10^{4} \mathrm{cfu} /$ radical. The population of NTG-mutants 102,218 and $343 \mathrm{R}^{\mathrm{R}} \mathrm{NA}^{\mathrm{R}}$ increased 2.5- to 4.5 -fold on the seed by 2 days after planting, but the population of NTG-403 $\mathrm{R}^{\mathrm{R}} \mathrm{NA}^{\mathrm{R}}$ decreased slightly (0.75-fold) during the same 2-day-period. The population of NTGmutants $\mathrm{R}^{\mathrm{R}} \mathrm{NA}^{\mathrm{R}}$ on individual radicals ranged from 1.2 to $6.8 \times 10^{5} \mathrm{cfu} / \mathrm{plant}$ by 2 days after sowing and increased 3.1- to 11.9-fold by 7 days after sowing.

\section{SEM observation of $P$. capacia in rhizosphere}

Radish seeds were coated with bacterial cells of the strain RB425 of $P$. cepacia at $10^{8} \mathrm{cfu} /$ seed using $0.1 \%$ methylcellulose as a carrier and then were sown in soil artificially infested with $R$. solani. Plants were recovered from the soil 24 and $48 \mathrm{hr}$ after sowing and observed under SEM. Several layers of bacterial rods were observed on the seed before and after sowing in soil (Fig. 1). The rod-shaped bacteria, possibly $P$. cepacia RB425, were also observed along the junction of epidermal cells of young root immediately after emergence from the seed (Fig. 2). These rods were observed to stick to the surface of root cells with fine threads (Fig. 2) and sometimes to be embedded in mucilaginous materials (Fig. 3). Colonies of the similar rodshaped bacteria were randomly located on the juvenile root surface, except at the root apex. Without bacterization, many hyphae of $R$. solani were observed to produce numerous short branch-like lobate appressoria ${ }^{5}$ and to form a hyphal mat on the surface of seeds and radicals newly emerged from the seeds. In contrast, with seed bacterization, only a few hyphae of $R$. 
Table 2. Effect of seed coating with live cells of Pseudomonas cepacia strain RB425 or its purified antibiotics on colonization of radish seedlings by Rhizoctonia solani and Rhizoctonia-induced damping-off of radish

\begin{tabular}{|c|c|c|c|c|}
\hline \multirow{2}{*}{$\begin{array}{l}\text { Strain or } \\
\text { antibiotic a) }\end{array}$} & \multirow{2}{*}{$\begin{array}{l}\text { Concentra- } \\
\text { tion/seed }\end{array}$} & \multicolumn{2}{|c|}{$\%$ Colonization $b)$} & \multirow{2}{*}{$\begin{array}{l}\text { Damping-off } \\
\text { Index }\end{array}$} \\
\hline & & Seed & Root & \\
\hline \multirow[t]{4}{*}{ RB425 } & $10^{5} \mathrm{cfu}$ & $82.7 \mathrm{~d}$ & $72.0 \mathrm{a}$ & $100.0 \mathrm{a}$ \\
\hline & $10^{6}$ & $96.0 \mathrm{ab}$ & $54.0 \mathrm{bc}$ & $94.2 \mathrm{abc}$ \\
\hline & $10^{7}$ & $48.0 \mathrm{f}$ & $22.0 \mathrm{~d}$ & $52.5 \mathrm{~d}$ \\
\hline & $10^{8}$ & $12.0 \mathrm{gh}$ & $18.0 \mathrm{~d}$ & $41.7 \mathrm{e}$ \\
\hline \multirow[t]{4}{*}{ Pyrrolnitrin } & $0.2 \mu \mathrm{g}$ & $72.0 \mathrm{e}$ & $48.0 \mathrm{c}$ & $90.0 \mathrm{c}$ \\
\hline & 1.0 & $46.7 \mathrm{f}$ & $56.0 \mathrm{bc}$ & $52.5 \mathrm{~d}$ \\
\hline & 2.0 & $16.0 \mathrm{~g}$ & $20.0 \mathrm{~d}$ & $40.8 \mathrm{e}$ \\
\hline & 10.0 & $4.0 \mathrm{~h}$ & $8.0 \mathrm{~d}$ & $11.7 \mathrm{f}$ \\
\hline \multirow[t]{4}{*}{ Pseudane (HMQ) } & $2.0 \mu \mathrm{g}$ & $96.0 \mathrm{ab}$ & $84.0 \mathrm{a}$ & $100.0 \mathrm{a}$ \\
\hline & 10.0 & $84.0 \mathrm{~cd}$ & $76.0 \mathrm{a}$ & $92.5 \mathrm{bc}$ \\
\hline & 20.0 & $100.0 \mathrm{a}$ & $68.0 \mathrm{ab}$ & $95.0 \mathrm{abc}$ \\
\hline & 40.0 & $92.0 \mathrm{abc}$ & $76.0 \mathrm{a}$ & $92.5 \mathrm{bc}$ \\
\hline \multirow[t]{4}{*}{ Pseudane (NMQ) } & $2.0 \mu \mathrm{g}$ & $96.0 \mathrm{ab}$ & $80.0 \mathrm{a}$ & $96.7 \mathrm{abc}$ \\
\hline & 10.0 & $88.0 \mathrm{bcd}$ & $72.0 \mathrm{a}$ & $100.0 \mathrm{a}$ \\
\hline & 20.0 & $100.0 \mathrm{a}$ & $82.0 \mathrm{a}$ & $100.0 \mathrm{a}$ \\
\hline & 40.0 & $100.0 \mathrm{a}$ & $76.0 \mathrm{a}$ & $94.2 \mathrm{abc}$ \\
\hline Control & - & $100.0 \mathrm{a}$ & $82.0 \mathrm{a}$ & $98.3 \mathrm{ab}$ \\
\hline
\end{tabular}

a) Pseudane HMQ and NMQ; 2-(2-heptenyl)-3-methyl-4-quinolinol and 2-(2-nonenyl)-3-methyl-4-quinolinol, respectively.

b) $\%$ of seeds or young roots from which hyphae of $R$. solani grow when the plant parts were placed on water agar plate. Each value was the average of three replicates and 25 plants were used in each replicate.

c) Damping-off index $=\frac{(2 A+1 B+0.5 C)}{2 T} \times 100$

$A$, pre-emergence damping-off; $B$, post-emergence damping-off; $C$, infected plants but not dampingoff; and $T$, total number of plants used.

Values followed by the same letter in each column are not significantly different at $\boldsymbol{P}=0.05$ according to Duncan's multiple range test.

Table 3. Population of Pseudomonas cepacia $\mathrm{RB} 425 \mathrm{R}^{\mathbf{R}} \mathrm{NA}^{\mathbf{R}}$ and NTG-induced mutants $\mathrm{R}^{\mathbf{R}} \mathrm{NA}^{\mathbf{R}}$ on the seeds and young roots of radish

\begin{tabular}{|c|c|c|c|c|}
\hline \multirow{3}{*}{$\begin{array}{l}\text { Strain of } \\
P . \text { cepacia }\end{array}$} & \multicolumn{4}{|c|}{ Population (cfu) per plant part and days a) } \\
\hline & \multicolumn{2}{|c|}{ Seed } & \multicolumn{2}{|c|}{ Young root } \\
\hline & Before & 2 days & 2 days & 7 days \\
\hline \multirow[t]{3}{*}{ RB425 R $\mathbf{R A}^{\mathbf{R}}$} & $9.4 \times 10^{6}$ & $11.6 \times 10^{6}$ & $4.6 \times 10^{6}$ & $10.2 \times 10^{6}$ \\
\hline & $4.7 \times 10^{5}$ & $8.2 \times 10^{5}$ & $1.8 \times 10^{4}$ & $1.2 \times 10^{5}$ \\
\hline & $9.3 \times 10^{4}$ & $6.4 \times 10^{5}$ & $5.3 \times 10^{3}$ & $3.5 \times 10^{4}$ \\
\hline NTG-102 R $\mathbf{R A}^{\mathbf{R}}$ & $7.0 \times 10^{6}$ & $17.8 \times 10^{6}$ & $4.5 \times 10^{5}$ & $1.4 \times 10^{6}$ \\
\hline NTG-218 $\mathbf{R}^{\mathbf{R}} \mathbf{N A}^{\mathbf{R}}$ & $5.4 \times 10^{6}$ & $23.0 \times 10^{6}$ & $6.2 \times 10^{5}$ & $7.4 \times 10^{6}$ \\
\hline NTG-348 $\mathbf{R}^{\mathbf{R}} \mathbf{N A}^{\mathbf{R}}$ & $3.8 \times 10^{6}$ & $17.0 \times 10^{6}$ & $6.8 \times 10^{5}$ & $6.0 \times 10^{6}$ \\
\hline NTG-403 R $\mathbf{R A}^{\mathbf{R}}$ & $10.4 \times 10^{6}$ & $7.8 \times 10^{6}$ & $1.2 \times 10^{5}$ & $1.4 \times 10^{6}$ \\
\hline
\end{tabular}

a) Population was counted on PPGSA medium containing $100 \mathrm{ppm}$ each of rifampicin and nalidixic acid, and $50 \mathrm{ppm}$ of cycloheximide by using a spiral plater apparatus. Population on seeds and young roots was counted before sowing and 2 days after sowing in soil, and 2 and 7 days after sowing, respectively. 
solani were observed on the seed and root surface and many rod-shaped bacteria were observed around and on the hyphae of $R$. solani (Fig. 4). The rods also appeared to adhere to the hyphae of $R$. solani by fine thread-like structures.

\section{DISCUSSION}

It appears from the high correlation between the ability of strains of $P$. cepacia to produce antibiotics and the ability of the same strains to suppress disease caused by $R$. solani on radish that the antibiotic production plays an important role in the suppression of radish damping-off by these strains introduced by seed bacterization. Strains RB425 and RB3292, grown in liquid culture produced $1.5-1.7,6.9-12.0$ and $4.3-7.9 \mu \mathrm{g} / \mathrm{ml}$ of pyrrolnitrin and two pseudane compounds, respectively, and were the most suppressive of all strains tested against damping-off of radish caused by $R$. solani. Strains A2 and A4 produced similar amounts of pyrrolnitrin (1.94 and $1.82 \mu \mathrm{g} / \mathrm{ml}$ ) as strain $\mathrm{RB} 425$ but did not produce either of the pseudane derivatives and exhibited less activity than strain RB425 against radish damping-off (Table 1). Natural and mutant strains, deficient for production of both pyrrolnitrin and the pseudanes, showed little or no activity against damping-off. Of the three antibiotics, pyrrolnitrin may be more important in disease suppression than either of the two pseudane derivatives, although the latter also may have some effect against damping-off of radish caused by $R$. solani. Further tests are needed with strains that produce pseudanes but not pyrrolnitrin to answer this question.

Several researchers have used antibiotic-deficient strains of antagonists to obtain evidence for the significance of antibiotic production in disease suppression; Pythium ultimum was controlled by a diketopeptide antibiotic, gliovirin, produced by Gliocladium virens, but a gliovirindeficient mutant was overgrown by $P$. ultimum in culture and did not protect cotton seedlings from damping-off in soil infested with $P$. ultimum ${ }^{12)}$. Gurrusiddaiah et al. ${ }^{6)}$ isolated a phenazine-type antibiotic from cultures of $P$. fluorescens 2-79 suppressive to take-all caused by Gaeumannomyces graminis var. tritici. Subsequent work revealed that inactivation of phenazine production in $P$. fluorescens $2-79$ by Tn5 mutagenesis resulted in greatly reduced ability of the strain to suppress take-all and restoration of antibiotic producing ability by complementation with DNA from the wild-type strain coordinately restored ability of the mutant strains to suppress takeall ${ }^{21)}$. Gutterson et al. ${ }^{7}$ ) showed that antifungal substances produced by $P$. fluorescens HV37a in vitro was at least partially responsible for limiting the incidence of preemergence damping-off of cotton seedlings caused by $P$. ultimum. While direct demonstration of the production of antibiotics by microorganisms in rhizosphere is very difficult, genetic manipulation of antagonists is a useful method for providing experimental evidence for the significance of antibiotic production to disease suppression in the rhizosphere.

Our conclusion, that antibiotic production plays an important role in suppression by microorganisms of Rhizoctonia-induced damping-off of radish, is further supported by the evidence that purified pyrrolnitrin coated on radish seed inhibited colonization of radish seeds and young roots by $R$. solani and suppressed the incidence of damping-off caused by $R$. solani (Table 2). This confirms the findings of Howell and Stipanovic ${ }^{10,11)}$, who demonstrated that purified pyrrolnitrin and pyoluteorin produced by a strain of $P$. fluorescens gave significant protection against Rhizoctonia- and Pythium-induced damping-off of cotton seedlings when coated on the seeds. The purified pseudane derivatives exhibited little or no effect against colonization of radish by the pathogen (Table 2), and provided no protection against disease, suggesting that pyrrolnitrin is more important than the pseudanes in suppression of damping-off of radish by $P$. cepacia.

It is clear from the SEM observations and by the monitoring the population of bacteria on radish seedlings, that the bacteria introduced on radish seeds multiplied in the spermosphere and then colonized the surface of young roots newly emerged from the coated seed. The behavior of $P$. cepacia on radish seedlings was very similar to that reported for $P$. fluorescens and $P$. putida on roots of potato ${ }^{3,16)}$, wheat ${ }^{24)}$, sugar beet ${ }^{20)}$ and maize ${ }^{19)}$ following bacterization 
of the seeds of these plants. $P$, fluorescens and $P$. putida multiplied in the spermosphere and then colonized seedlings of soybean ${ }^{17}$. The early events of colonization of the surface of young roots of radish by the bacteria introduced in seeds was similar to the pattern reported by van Vuurde $e t$ al. $^{23)}$ for rhizobacteria on wheat, namely, colonization of longitudinal junctions of epidermal cells first followed by spreading over the cell surface. It is also clear that without bacterization, $R$. solani rapidly colonized the seed of radish, attacked young roots as they emerged from the seeds, and killed the seedling within $48 \mathrm{hr}$ after sowing, whereas with bacterization, the colonization of young plants by $R$. solani was inhibited by the bacteria and damping-off was reduced. These results suggest that $P$. cepacia colonized and occupied the infection court, including the surface of seeds and young roots, and produced the antibiotics inhibitory to the pathogen as a colonist of young plants.

The authors thank Dr. R. James Cook, U.S. Department of Agriculture, Agriculture Research Service, Washington State University, Pullman, Washington 99164, USA for critically reviewing this manuscript, and Dr. Z. Dato, National Institute of Agro-Environmental Sciences, Tsukuba, Ibaraki 305 Japan, for useful suggestion. Thanks are also due to Dr. S. Wakimoto, Kyushu University, for his kind supply of bacterial strains.

\section{Literature cited}

1. Brown, M.E. (1974). Ann. Rev. Phytopathol. 12: 181-197.

2. Burkholder, W. (1942). Phytopathology 32: 141-149.

3. Burr, T.J., Schroth, M.N. and Suslow, T. (1978). Ibid. 68: 1377-1383.

4. Cook, R.J. and Baker, K.F. (1983). The Nature and Practice of Biological Control of Plant Pathogens. APS, St. Paul, Minnesota. pp. 111-115, 163-165.

5. Dodman, R.J. and Flentje, N.T. (1970). In Rhizoctonia solani: Biology and Pathology (Parmeter, T.R., Jr. ed.). Univ. California Press, Berkeley. pp. 149-160.

6. Gurrusiddaiah, S., Weller, D.M., Sarker, A. and Cook, R.J. (1986). Antimicrob. Ag. Chemoth. 29: 488-495.

7. Gutterson, N.I., Langton, T.J., Ziegle, J.S. and Warren, G.J. (1985). J. Bacteriol. 165: 696-703.

8. Homma, Y., Sato, Z., Hirayama, F., Konno, K., Shirahama, H. and Suzui, T. (1985). Ann. Phytopath. Soc. Japan 53: 543 (Abstr. in Japanese).

9. Homma, Y., Sato, Z., Hirayama, F., Konno, K., Shirahama, H. and Suzui, T. (1989). Soil Biol. Biochem. 21: 723-728.

10. Howell, C.R. and Stipanovic, R.D. (1979). Phytopathology 69: 480-482.

11. Howell, C.R. and Stipanovic, R.D. (1980). Ibid. 70: 712-715.

12. Howell, C.R. and Stipanovic, R.D. (1983). Can. J. Microbiol. 29: 321-324.

13. Kado, C.I. and Haskett, M.G. (1970). Phytopathology 60: 969-976.

14. Kawamoto, S.O. and Lorbeer, J.W. (1976). Plant Dis. Repr. 60: 189-191.

15. Kirinuki, T., Iwanuma, K., Suzuki, N., Fukami, H. and Ueno, T. (1977). Sc. Repr. Fac. Agr., Kobe Univ. 12: 223-230.

16. Kloepper, J.W., Schroth, M.N. and Miller, T.D. (1980). Phytopathology 70: 1078-1082.

17. Kloepper, J.W., Scher, F.M., Laliberte, M. and Zaleska, I. (1985). Can. J. Microbiol. 31: 926929.

18. Parker, W.L., Rathnum, M.L., Seiner, V., Trejo, W.H., Principe, P.A. and Sykes, R.B. (1984). J. Antibiot. 37: 431-440.

19. Scher, F.M., Ziegle, J.S. and Hancock, J.G. (1984). Can. J. Microbiol. 30: 151-157.

20. Suslow, T.V. and Schroth, M.N. (1982). Phytopathology 72: 199-206.

21. Thomashow, L.S. and Weller, D.M. (1987). Ibid. 77: 1724.

22. Tsuchiya, K., Akhter, T., Takasaki, T., Tanaka, S. and Wakimoto, S. (1986). Ann. Phytopath. Soc. Japan 52: 825-834.

23. Van Vuurde, J.W.L., Kruyswyk, C.J. and Schippers, B. (1979). In Soilborne Plant Pathogens (Schippers, B. and Gams, W. eds.). Academic Press, London. pp. 229-234.

24. Weller, D.M. (1983). Phytopathology 73: 1548-1553. 


\section{和 文 摘 要}

本間善久・鉿井孝化：Pseudomonas cepacia の種子バクテリゼーションによるダイコン苗立枯病の抑制に 打於抗生物質生産の意義

Pseudomonas cepacia RB425 扤よび RB3292 は，抗生物質ピロールニトリンおよびシューダン (HMQ, NMQ) を生産し，ダイコン種子にコーティングすることによって，Rhizoctonia solani とよる苗立枯病を抑 制した。Cymbidium spp. の褐色斑点細菌病菌 P. cepacia A2 および A4 は, シューダンは生産しないがピ ロールニトリンを生産し, 発病抑制効果が認められた。P. cepacia ATCC No. 25416 は, いずれの抗生物 質も生産せず，抑制効果がなかった。ニトロソグアニジンで誘導した RB425 の突然変異株 8 菌株は抗生物 質生産性飞変異が認められ, 培地上の 3 種の抗生物質生産性と, R. solani の幼苗への着生率抑制就よび発 病抑制能との間に高い相関関係が認められた。種子当り $10^{7} \mathrm{cfu} の \mathrm{RB} 425$ の生菌または, $1.0 \mu \mathrm{g}$ の純化し たピロールニトリンを種子にコーティングすることによって，执よそ $50 \%$ の発病抑制率が得られた。シュ 一ダンを種子当り $40 \mu \mathrm{g}$ コーティングした場合には，ほとんど抑制効果がなかった。 RB425 のリファンピ シン拈よびナリジキシ酸耐性菌株を用いて播種後の菌数を測定したところ, 種子当り $9.4 \times 10^{6}, 4.7 \times 10^{5}$ 物 よび $9.4 \times 10^{4} \mathrm{cfu}$ ニーティングした場合, 7 日目に幼根 $1 \mathrm{~g}$ 当り $4.6 \times 10^{5}, 1.8 \times 10^{4}$ 打よび $5.3 \times 10^{3} \mathrm{cfu}$ で あった。種子コーティングした RB425 は，播種後，幼根表皮細胞の縫合部に沿って生育し，根圈で增殖 するのがSEM によって観察された。これらの結果から，P. cepacia RB425 はダイコン幼苗根圈で增殖でき， 種子コーティングによるダイコン苗立枯病の抑制効果にピロールニトリンが重要な役割を有すると考えられ た。

\section{Explanation of plate}

Plate I.

Scanning electron micrographs of Pseudomonas cepacia and Rhizoctonia solani on seeds and young roots of radish grown in garden soil; 1 . Bacterial cells of $P$. cepacia several layers thick on seed surface at $20 \mathrm{hr}$ after sowing in soil (bar $=5 \mu \mathrm{m}$ ). 2 . Rods, possibly the cells of strain RB425 of $P$. cepacia, along the junction of epidermal cells of young roots and attached to root cells by fine threads at $20 \mathrm{hr}$ after sowing in soil (bar $=6 \mu \mathrm{m}$ ). 3. Rods embedded in mucilaginous materials on the surface of young roots at $48 \mathrm{hr}$ after sowing ( $\mathrm{bar}=10 \mu \mathrm{m})$. 4. Hyphae of $R$. solani on the seed with bacterization and colonized by rod-shaped bacteria at $48 \mathrm{hr}$ after sowing in the soil infested with $R$. solani (bar $=20$ $\mu \mathrm{m})$. 


\section{Plate I}
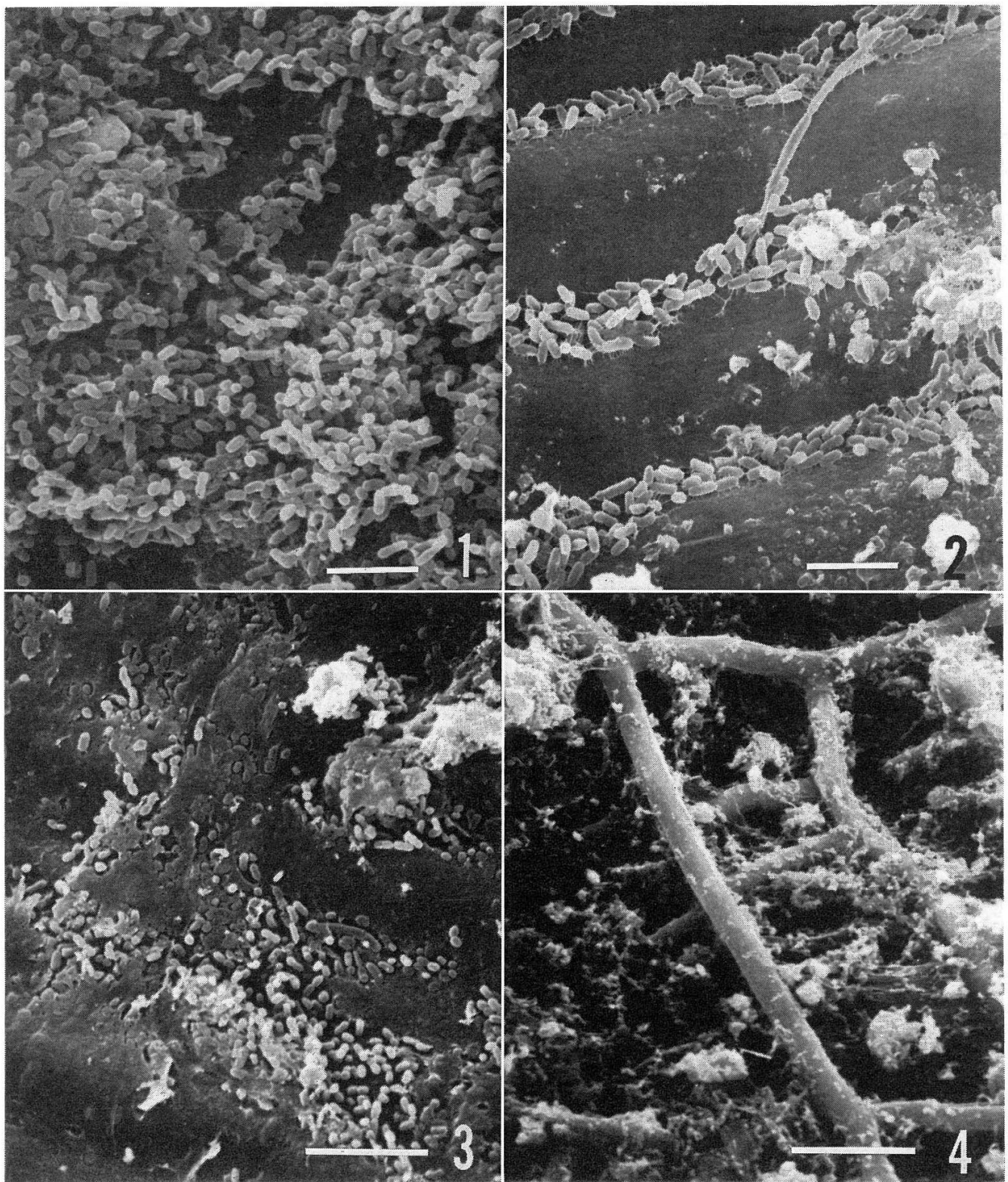